\title{
ARCHAEOLOGY OF THE ST. NICHOLAS CHURCH IN DEMOLISHED VILLAGE OF LIBKOVICE (LIQUITZ) - EXCAVATIONS IN 1995-1996 (NORTH BOHEMIAN BROWN COAL MINING AREA). A CONTRIBUTION TO THE RESEARCH OF MEDIEVAL VILLAGE CHURCHES IN BOHEMIA
}

\author{
PAVEL VAŘEKA
}

\begin{abstract}
Exploratory and rescue archaeological research in the village of Libkovice (distr. of Most) in 1991-1999, which was demolished due to planned coal mining, also focused on the parish church of St. Nicholas built there in the 1890s. Excavations have revealed well preserved masonry of the original Early-Gothic church from the 13th century and remains of an earlier structure, which can indicate a timber sacral building. Establishment of the earliest sacral building with an annexed graveyard in the nucleation core of the settlement represented an important phase of the stabilised village formation. Archaeology thus has brought direct material evidence of the process of the establishment of village parishes and graveyards. On-going research in Libkovice provides further extensive information, making it possible to verify results of the field research in the 1990s and broaden the potential of the site as an important reference sample for the wider programme focused on inhabited historical villages in Bohemia but also in wider European context.
\end{abstract}

Key words: medieval village church - medieval timber church-early medieval settlement - medieval village-contemporary village - village formation.

Archeologie kostela sv. Mikuláše ve zbořené obci Libkovice (Liquitz) - sondáže v letech 19951996 (Severočeská hnědouhelná pánev). Př́spěvek k výzkumu středověkých vesnických kostelů v Čechách

Abstrakt: Zjištovaci a záchranný archeologický výzkum ve vsi Libkovice (okres Most) v letech 1991-1999, zbořené v důsledku plánované těžby uhlí, se zaměril také na farní kostel sv. Mikuláše zbudovanýv 90. letech 19. století. Sondáž odhalila dobře dochované zdivo pưvodního raně gotického kostela ze 13. století a liniový objekt, který může indikovat starši dřevěnou sakrálni stavbu. Zbudováni kostela v nukleačním jádru sídliště představovalo důležitou etapu ve formováni stabilizované vesnice, a to společně se zř́zením hřbitova. Archeologie tak přináši materiální doklady spojené se zřizováním vesnické farní organizace a kostelních hřbitovi̊. Současný plošný záchranný výzkum v areálu Libkovic poskytuje další rozsáhlé informace, které umožňuji ověřit poznatky ziskané v 90. letech a zároveň rozšiřuji potenciál lokality jako významného referenčního vzorku pro širši program studia existujících vsí středověkého původu v Čechách, ale i v širším evropském kontextu.

Kličová slova: středověký vesnický kostel-středověký dřevěný kostel-raněstředověké sídliště-středověká vesnice-současná vesnice-formování vesnice.

\section{Archaeology of the village of Libkovice}

The site is located in the Most Basin in north-western Bohemia, which is lined by the Ore Mountains (Krušné hory/Erzgebirge) from the northwest and by the Central Bohemian Uplands (České středohoří/Böhmische Mittelgebirge) from the southeast. This area, which stretches $1400 \mathrm{~km}^{2}$, was formed geologically in the Tertiary and consists of Eocene and Miocene complexes including large coal seams, which are covered by Quaternary sediments such as terrace sands and gravels, deluvial and proluvial clastics, loess and lake clay sediments. The studied site is located in the Lomský stream valley, in the lower part of which fertile brown soils developed on loess; its upper part near the foothills of the Ore Mountains is covered with clays, gravels and sands (Pešek at al. 2010, 61-64; Pešek-Sivek 2012, 107-109).

The village of Libkovice was demolished due to coal mining in the 1990s. Coal extraction has a long tradition in North West Bohemia (e. g., Luxa 1997; Matějček 1984); however, it increased dramatically during the communist era in the 1950s-1980s (Nesládek-Novotná 1985). The giant state enterprise Severočeské hnědouhelné doly (North Bohemian Brown Coal Mines) 
began large scale surface mining in huge quarries covering dozens of square kilometres, the production of which culminated in the 1980s when more than 70 million tons of coal were mined here per year (Nesládek-Novotná 1985, 575). Ruthless mining has not only ravaged the cultural landscape (formed since prehistory over thousands of years), caused unimaginable and permanent ecological damage, but also led to the extinction of many historical settlements. A total of 30 villages representing one third of the historical communities in the Most District disappeared during the 1950s-1980s due to coal mining, including the medieval royal town of Most (Brüx) itself, which was demolished. ${ }^{1}$ The town and surrounding area was turned into a huge mine and a new city was built in the vicinity in the 1960s-1980s. Further settlements were destroyed in other parts of the North West Bohemian coal mining area (Gockeler-Reeve 1997, 174-175).

The Lom stream valley with numerous remains of the continuous intensive settlement from the Neolithic has attracted archaeologists since the late 19th century (e. g., Budinský 1968; 1970; Waldhauser 1978); however, the most intensive excavations took place in the 1970s-1990s. The spread of the Maxim Gorki (later Bílina) coal mine gradually engulfed the whole valley from the East to the West and therefore large scale rescue excavations were undertaken, esp. in the poly-cultural localities Břežánky, Hrdlovka and Jenišův Újezd (e. g., Beneš 1991a; 1991b; 1995; 1995b; Beneš-Koutecký 1987; Bubeník 1975; Bubeník-Velímský 1986; Meduna 2012), but also systematic surface collection of artefacts on arable land (project "Ancient Landscape Reconstruction in North Bohemia"; Beneš-Kuna-Peške-Zvelebil 1992; Beneš-Zvelebil 1996). Currently the area of the former village of Libkovice is endangered by the Bílina mine (Severočeské doly, a. s. North Bohemian Mines, joint-stock company) producing 10 million tons of coal per year, which will totally destroy this part of the Lom stream valley by 2035 (https://www.sdas.cz/aktivity/ hornicka-cinnost/doly-bilina.aspx).

Due to the planned demolition of the village and extensive mining on its cadastral territory, exploratory and rescue archaeological excavations organised originally by the Most branch of the Institute of Archaeology Czechoslovak Academy of Sciences and later by the Institutes for Archaeological Heritage of North West and Central Bohemia were carried out in 1991-1999. Theoretical approaches and methods were based on medieval settlement studies, esp. high medieval settlement transformation research in Bohemia (Klápště 1994b) and also built upon earlier rescue archaeological activities concentrated on historical cores of inhabited villages in this region (Klápště 1994a, 27-90). The research results initiated a wider programme focused on inhabited historical villages in Bohemia, making Libkovice the main reference sample. The theoretical and methodological framework of this programme was already defined in the 1990s (Nováček-Vařeka 1996; 1997) and it has been developing ever since (e. g., Dohnal-Korený-Koucký-ProcházkaŠamata 2001; Dohnal-Vařeka 1997; Meduna-Kypta-Šulc-Matějek 2001; Militký-Vařeka 1997; Nováček 1997; Vařeka 2013; 2001; Vařeka-Kostrouch-Kočár-Sůvová 2010). The Libkovice project also represents one of the very few systematic archaeological research activities focusing on a contemporary village of medieval origin in Europe. ${ }^{2}$ It had five main objectives regarding the medieval, post-medieval and modern village development: 1) early medieval settlement pattern, 2) high medieval settlement transformation and origins of the nucleated village, 3) later medieval village and farms, 4) parish church and the churchyard, 5) post-medieval village development, and 6) impact of the 19th century industrial revolution (Vařeka 2001, 86).

The main task of the research carried out in the 1990s was to obtain maximum data from the whole territory of the historical core of the village under the given circumstances, i. e. limited resources and time. Field research applied a combination of long $1 \mathrm{~m}$ wide trenches and archaeological interventions (usually several square metres) situated in open areas such as the

1 Extensive rescue archaeological research of the medieval town of Most see e. g. Klápště 1975; 2002; Klápště-Slavíček-Velímský 1976; Klápště-Velímský 1975.

2 E. g. Hinz 1977; Lewis 2014; 2015; 2016; Oexle 2002; Smolnik 2011. An extensive European project focused on contemporary villages see Community Archaeology in Rural Environments - Meeting Societal Challenges (CARE-MSoC), JPICH Heritage in Changing Environments (https://www. researchgate.net/publication/330314005_Community_Archaeology_in_Rural_Environments_-_Meeting_Societal_Challenges_CARE-MSoC). 
village green and communications, within individual house-plots, inside dwelling houses and outhouses and, last but not least, in the churchyard. Field sampling provided data of both a linear and point character regarding the original relief of the valley, its changes, earlier settlement activities, village formation, development of farms, mills, public areas, the church and graveyard. The stratigraphic situation in gardens and adjacent fields was also randomly tested. A total of 131 trenches and interventions were excavated over the course of 9 years.

Currently large scale rescue excavations of the whole microregion have been launched by the Institute of Archaeological Heritage of North-West Bohemia in cooperation with the Department of Archaeology of the University of West Bohemia and Wrocław University of Environmental and Life Sciences which are based on results of the previous research. The on-going project shall provide complex archaeological, environmental and historical evidence regarding the former village of Libkovice over the next ten years.

\section{Village formation and development}

The village of Libkovice is situated in the upper part of the wide Lom stream valley, $3 \mathrm{~km}$ SouthEast of the foothills of the Ore Mountains (Krušné hory, Erzgebirge), which form the natural border between Bohemia and Saxony. Trial excavations showed that the contemporary flat bottom of the valley evolved due to complicated formation processes, esp. erosion and accumulation. The lowest part of the valley is filled with sediments reaching 1-2 $\mathrm{m}$, the accumulation of which is the result of a combination of natural and human factors. Numerous Neolithic, Eneolithic and Bronze Age artefacts indicate massive erosion of the slopes and terrace edges with remains of prehistoric settlement activities, but also the effect of the stream, which originally meandered in the valley. The earliest intact settlement remains near the stream are dated to the Eneolitic, Bronze and Iron Age.

According the current archaeological data, the early medieval settlement underneath the later village was established in the 7 th-8th century. The earliest village was very likely represented by several components which may indicate a dispersed settlement form consisting of several isolated farms situated along the stream. Due to the later village development, only fragmentary remains of the early medieval settlement have been preserved.

Excavations revealed dense settlement traces from the 10th/11th - early 13th century around the later parish church and in its southern and western vicinity, which indicate the nucleation core of the stabilised high medieval village (Fig. 1). It seems, however, that the new settlement form consisted of farms built in the archaic early medieval tradition, with characteristic types of archaeological features (various pits and remains of probably small one-compartment surface wooden houses) and sequences of waste layers. The earliest phase of a mill-race and a feature which can be interpreted as a pit for the mill-wheel attests to the earliest mill, which may have been situated in the earliest village core. The second mill, situated $500 \mathrm{~m}$ up the stream, might have been established before the middle of the 13th century together with a small pond retaining water for both mills. According to numerous finds of slag and redeposited remains of furnaces, iron-production must have taken place in the 10th/11th - early 13th century village. The early form of the nucleated village can be linked to the first documentary evidence from 1240 when part of "villam Lubcowitz" was bought by the Abbot Slavko of the nearby Osek Cistercian monastery. Archaeological dating of the earliest phases of mills (Fig. 1:b-c) corresponds with the mention of "duobus molendinis" in the charter (CDB III/2, No. 261, 356-357). Establishment of the parish church and churchyard must have represented an important step in the process of the village's formation. The church appeared indirectly in written records in 1282 by mentioning the priest Heinrich (Regesta IV, No. 1851, 737), however its earlier foundation can be elucidated by archaeological records (see below).

The second phase of the stabilized village formation occurred probably in the late 13th13th/14th century. In this period, the village with a developed normative layout was established 


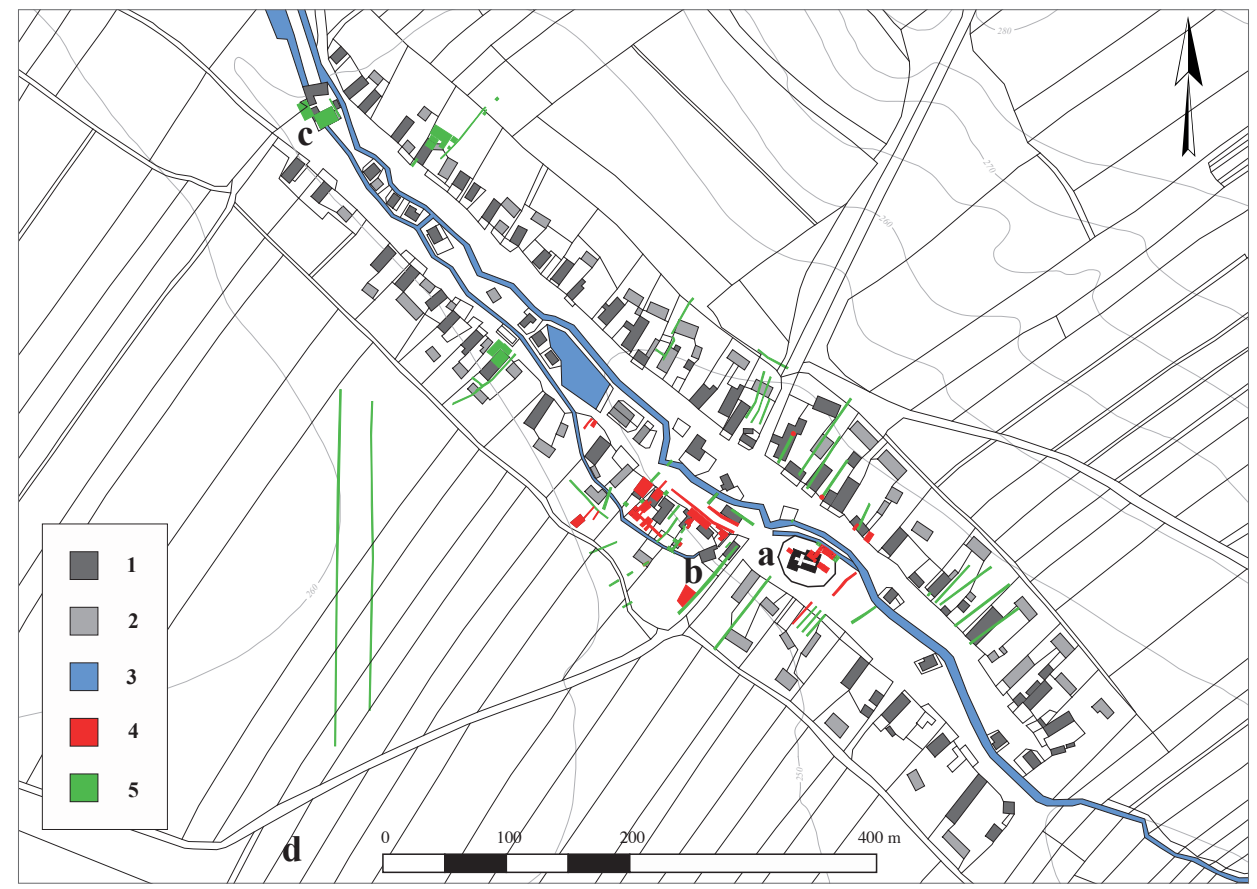

Fig. 1. Libkovice - Cadastral Map 1842 with projected contour lines and archaeological interventions from 1991-1999. a Gothic St. Nicholas church; b-c-mills; d - possible location of the early medieval row cemetery; 1 - masonry built houses; 2 timber buildings; 3 - stream, ponds and millrace; 4 - archaeological interventions with detected remains of the 10th/11th early 13th century indicating nucleation core of the village; 5 - other archaeological interventions. Map by P. Vařeka.

Obr. 1. Libkovice - mapa stabilního katastru z roku 1842 s průmětem vrstevnic a archeologickými sondami z let 1991-1999. a - gotický kostel sv. Mikuláše; b-c - mlýny; d - možná poloha raně stř̌edověkého řadového pohřebiště; 1 - nespalné domy zděné konstrukce; 2 - dřevěné stavby; 3 - potok, rybníky a mlýnský náhon; 4 - archeologické sondy, které zachytily stopy osídlení z 10./11. - počátku 13. století indikující nukleační jádro vesnice; 5 - další archeologické sondy. Mapa P. Vařeka.

and consisted of two rows of farms lining a long village green with a stream flowing in its middle (Fig. 1). Archaeological evidence showed that individual house plots have not changed since the late Middle Ages until the early 19th century, when the village plan was mapped in detail for the first time (Cadastral Map 1842). Excavations demonstrated that in all studied cases the modern farm houses are superimposed on the late medieval and post-medieval buildings. The gable position of the buildings was very stable and situated along one of the longer sides of the house plot. Three-compartment houses were built of wood in the 13th/14th-17th century and their presumably corner-timbered or half-timber walls rested on stone foundations or were set in shallow grooves in the ground. Some construction remains indicate outhouses situated around central yards which were provided with simple pavement since the late middle ages. The documentary evidence shows a number of peasants/houses varying from 41 in 1579 (Urbar), 38 in 1652 (Berní rula), 49 in 1713 (Tereziánský katastr) and 70 in 1781 (Schaller 1781, 153), which corresponds with the size of the historical core of the village established in the later medieval period but also demonstrates gradual population growth after the Thirty Years' War. The growth was reflected in building of several new houses in the area of the village green during the 18th century.

The earliest preserved standing village house (demolished in the 1990s), which was dated to the late 18th century, illustrates the character of rural architecture before the industrial revolution. It was a storey house with a stone-built ground floor and half-timbered first floor. It has a threecompartment internal structure consisting of a central entrance room with black kitchen in the 
back, living room on the front gable side facing the village green and a stable situated on the other side (typical Central European byre house; cf. Vařeka 2018, 139).

The village changed dramatically in the late 19th century due to rapid industrialization of the region, esp. the development of coal mining. The arrival of miners and workers, and related accommodation needs, caused the rebuilding of many original farms and enlargement of the village. The population of Libkovice increased seven-fold over the course of one hundred years: in 1833 it had 321 inhabitants living in 71 houses (Sommer 1833, 151); in 1930 the population had reached 2,314 people and the village consisted of 258 houses (Kol. 1978, 514). The agricultural character of the settlement changed as a result of establishment of several enterprises such as glassworks or brick or pottery factories.

Ethnically, the village was divided into Czechs and Germans before the Second World War. Farmers representing the original or at least early-modern and modern population were Germans; the miners and workers, who began coming in the end of the 19th century from inland, were mostly Czechs. After the war, the most inhabitants of German ethnicity were expelled, as in the whole so-called Sudetenland of former Czechoslovakia. Post-war stagnation, which was evident in the gradual reduction of the population and abandonment of houses (1,181 inhabitants in 1970), was completed by the decision to extend the mining zone towards Libkovice. The fate of the village was sealed on 30th October 1990 when a decree of demolition was issued by the local authorities (Gockeler-Reeve 1997, 34, 154).

\section{St. Nicolas Church}

St. Nicholas Church in Libkovice was mentioned for the first time in 1282, when the local priest donated a mill in Obrnice to the convent in Osek (Regesta IV, No. 1851, 737). Documentary evidence regarding confirmation of priests (LC VI, 120, 205, 208) show that it was a parish church administered by the Cistercian monastery in Osek. The church was repaired in 1666 due to damage of some kind, which can be linked to the mention of traces of a fire on the church walls at the end of the 19th century (Novosadová 1988,2). The original church was demolished in 1893 due to poor building conditions and a new one was built in 1893-1896 in a historicizing style characterized by the eclectic combination of late renaissance and baroque but also classicist and neo-romanticist elements (Novosadová 1988, 35-36).

The older church depicted on the cadastral map from 1842 is situated in the same place as the later building; however, it had a different rectangular layout and orientation (Fig. 1). In accordance with canonical rules, its longitudinal axis is placed in a west-east direction, whereas the orientation of the later church respects the axis of the regular long village green (northwestsoutheast orientation). The appearance of the original church is captured on a drawing from the late 19th century (view from the northeast; Vařeka 1996, Tab. 7). The picture depicts a church of a rectangular layout; its presbytery and nave are furnished with separate saddle roofs of unequal height, probably covered with shingles (Fig. 2). On the top of the nave's roof, a small slender octagonal bell tower probably of a wooden construction can be seen. Another small octagonal bell tower with a Baroque onion-shape roof is situated in the eastern part of the rooftop of the presbytery. The top of the gable wall of the presbytery is decorated with a tiny pinnacle. A low vestry is placed at the north-west corner of the presbytery. A pair of high windows with a pointed arch is placed in the northern wall of the presbytery and only one smaller window with a pointed arch illuminates the nave. The church is surrounded by a stone wall. Given the overall form of the church, especially the rectangular presbytery without buttresses, it can be classified as an early Gothic sacral building showing similarities with several small village churches in Bohemia dated to the second and third quarter of the 13th century (e. g., Líbal 1984, 154, 166).

Projection of the 1842 map onto the contemporary situation showed that the earlier church is very likely situated underneath the contemporary building, with the exception of its north-eastern part and the south-western corner extending outside the contemporary church layout (Fig. 3:c). 


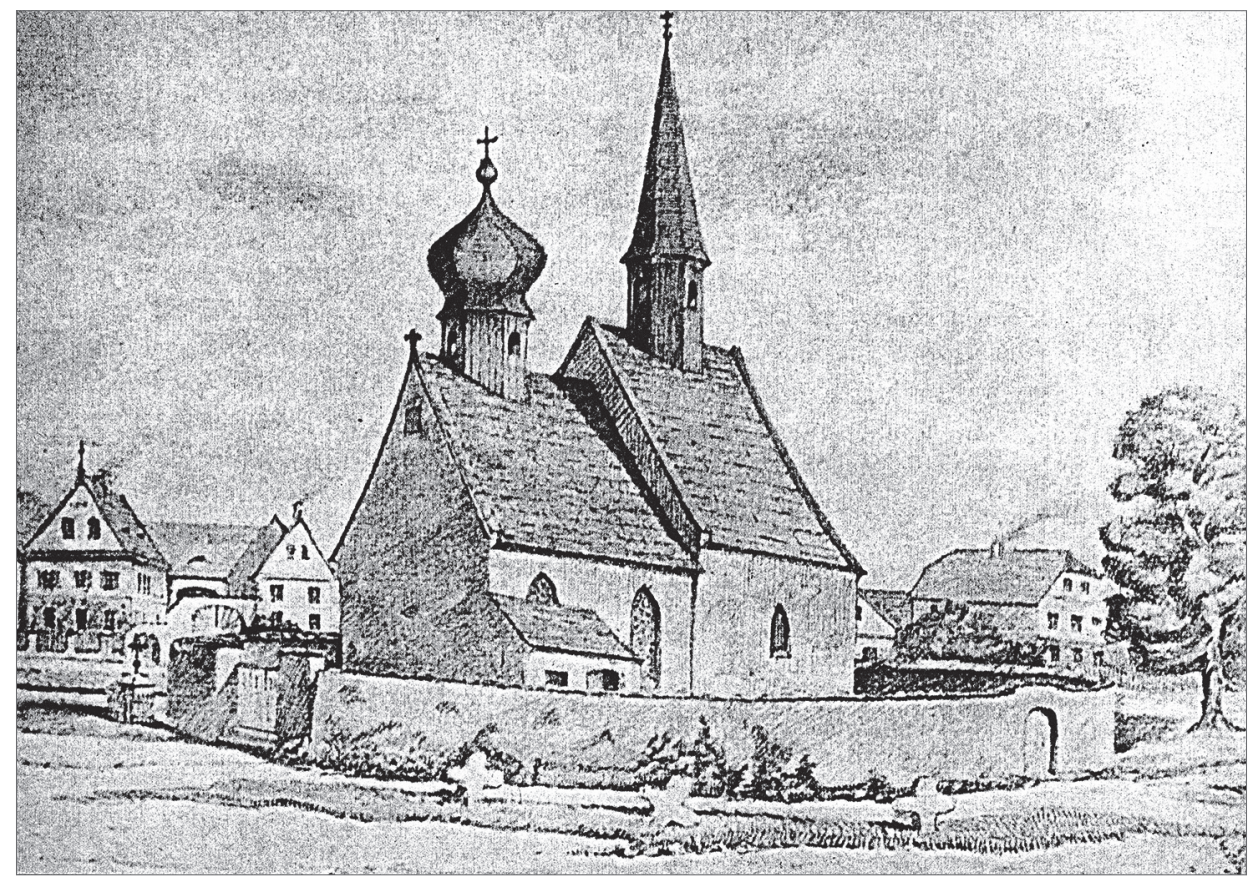

Fig. 2. Late 19th century drawing of the Gothic St. Nicholas church in Libkovice. After Vařeka 1996.

Obr. 2. Vyobrazení gotického kostela sv. Mikuláše v Libkovicích z konce 19. století. Podle Vařeka 1996.

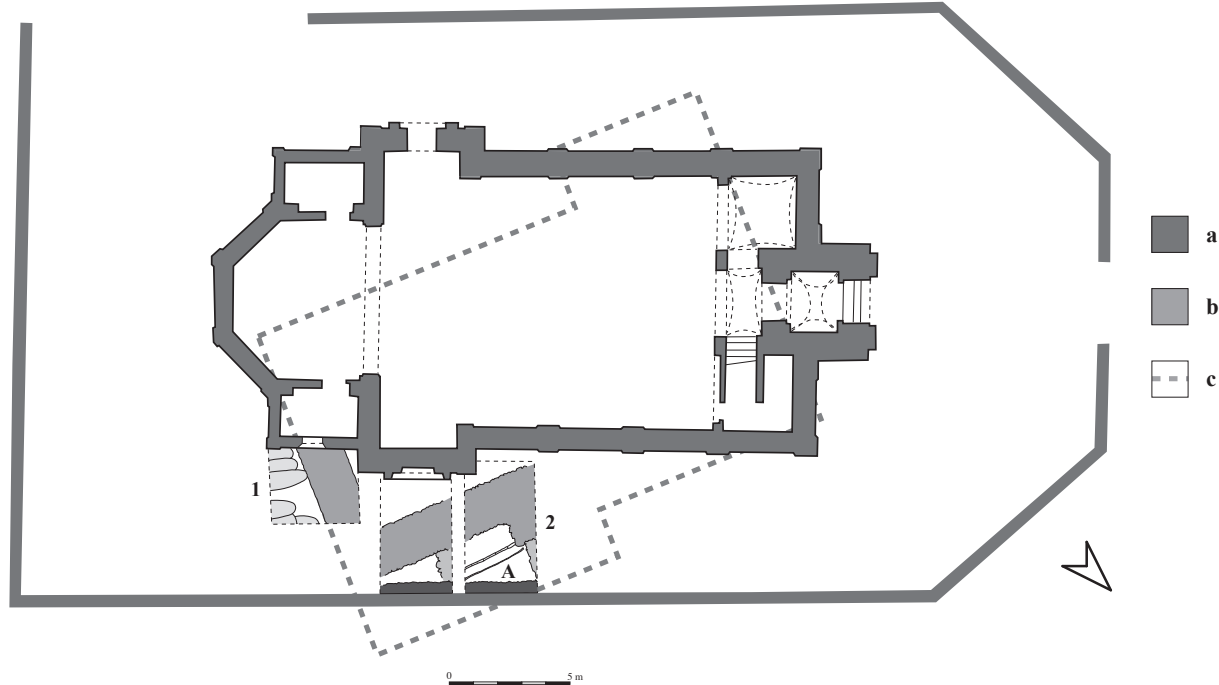

Fig. 3. Libkovice - St. Nichols church. a - modern church built in 1893-1896; $b$ - foundations of the Gothic church revealed by the excavations in 1995-1996; $\mathrm{c}$ - reconstruction of the layout of the Gothic church; A-probable foundation trench of the earlier timber church; 1 - intervention 92 with marked (grey) graves; 2 -intervention 95. Plan by A. Majer, V. Mráz and P. Vařeka. Obr. 3. Libkovice - kostel sv. Mikuláše; a - moderní kostel z let 1893-1896; b - základy gotického kostela odhalené odkryvem v letech 1995-1996; c - rekonstrukce půdorysu gotického kostela; A - možný relikt základů staršího dřevěného kostela; 1 sonda 92 s šedě označenými hroby; 2 - sonda 95. Plán A. Majer, V. Mráz, P. Vařeka. 
Due to the fact that the church interior was not accessible for archaeological research (safety matters regarding structural problems of the building), sample excavations focused on the presumed north-eastern section of the old church. Two interventions $\left(\mathrm{ca} .40 \mathrm{~m}^{2}\right.$ ) revealed a $1.2 \mathrm{~m}$ thick wall of the earlier church, which has been preserved to a height of max. $0.8 \mathrm{~m}$ (Fig. 3:b, Fig. 6). The wall was built of boulders, cobbles and rarely also of quarry stones which were bound by lime mortar, the quality of which decreases in the lowermost section. A commission proceedings report on church building conditions from 1893 characterizes the church masonry as consisting of cobbles bound by mortar of a poor quality or even a clay with only corners reinforced with sand stone blocks (Novosadová 1988, 6). The unearthed section of the church corresponds with the rectangular presbytery, which is depicted both on the cadastral map and the drawing (see above) with an annexed vestry, the later archaeological dating of which is demonstrated by a gap and the different character of the masonry. Several pottery sherds found in the vestry wall can be dated to the 14th - early 15th century. Excavated foundations of the church and the 1842 map make it possible to reconstruct the whole layout of the Gothic church which had ca. $10 \mathrm{~m}$ in width and $21.5 \mathrm{~m}$ in length (outer size without vestry and south-western annex).

Remains of the churchyard are adjoined to the eastern wall of the church (intervention 92) with six graves situated in super-positions in west-east orientation (Fig. 3:1). Graves from a stratigraphically later level contained artefacts that can be dated to the 17th-18th century (dress accessories, coffin decorations). Partially disturbed earlier graves mostly produced fragments of redeposited prehistoric, medieval and post-medieval pottery, nails (probably from wooden coffins) but also a medieval arrowhead was found by the right side of one individual (a grave-good?). No graves were found in the area along the northern wall of the presbytery (intervention 96) due to the fact that the vestry was situated there. This is why the well-preserved sequence of archaeological contexts reaching $1.4 \mathrm{~m}$ has been preserved here, making it possible to study the earlier settlement (Fig. 4:2, Fig. 4:3 and Fig. 5).

The first horizon documents settlement activities connected with the earliest village development (Fig. 4:1 and Fig. 4:3). The initial settlement evidence is represented by layer 95010 (settlement phase 1) covering the gravel subsoil that produced a small set of early medieval pottery (39 pieces), the determinable fragments of which (15 pieces) can be only generally classified to the 10th/11th-12/13th century with possible intrusion of the 9 th-10th century pottery (Fig. 7:1-7), ${ }^{3}$ as well as prehistoric ceramics ( 34 pieces) and stone artefacts ( 2 pieces). Fragments of iron furnaces (14 pieces) and iron slag (49 pieces, $686 \mathrm{~g}$ ) indicate that iron production must have taken place in the vicinity. Two successive post-holes $(95015,95023)$ and areas covered with gravel, pebbles and small stones $(95017,95022)$ show settlement activities of some kind (settlement phase 2; Fig. 4:1). The subsequent thick settlement layer 95007 (settlement phase 3) was divided into two levels (9007a and 9007b), the earlier of which provided evidence of what was very likely a surface building represented by a stone footing of a timber wall (95018) supported by a post (post-hole 92020). The building was burnt down, as is indicated by a layer of charcoals and burnt daub fragments (95019). A shallow pit, probably an another post-hole, belongs to the same phase (95013; Fig. 4:2). The layer 95007 and other contexts (95019 - fill of the post-hole, burnt layer 95020) from this phase produced a total of 255 pottery shards ( $4.934 \mathrm{~g})$ of early medieval fabric, 56 of which were determined (rims, decorated fragments) and can be mostly dated to the 12 th- 12 th/13th century. ${ }^{4}$ Eight fragments of the 9th-10th century pottery as well as three prehistoric shards most likely represent an intrusion of re-deposited artefacts (Fig. 7:9-34).

\footnotetext{
3 Pottery dating is based on chronological phases defined by J. Klápště (1994a, 92-112) and P. Meduna (2012, 40-45).

4 Determinable pottery fragments predominantly correspond with Phase E1 and only few can be linked to Phase D defined by P. Meduna $(2012,44)$. Similarly, the pottery set largely resembles the earliest phase of the late early medieval pottery delineated by J. Klápště (1994a, 94).
} 

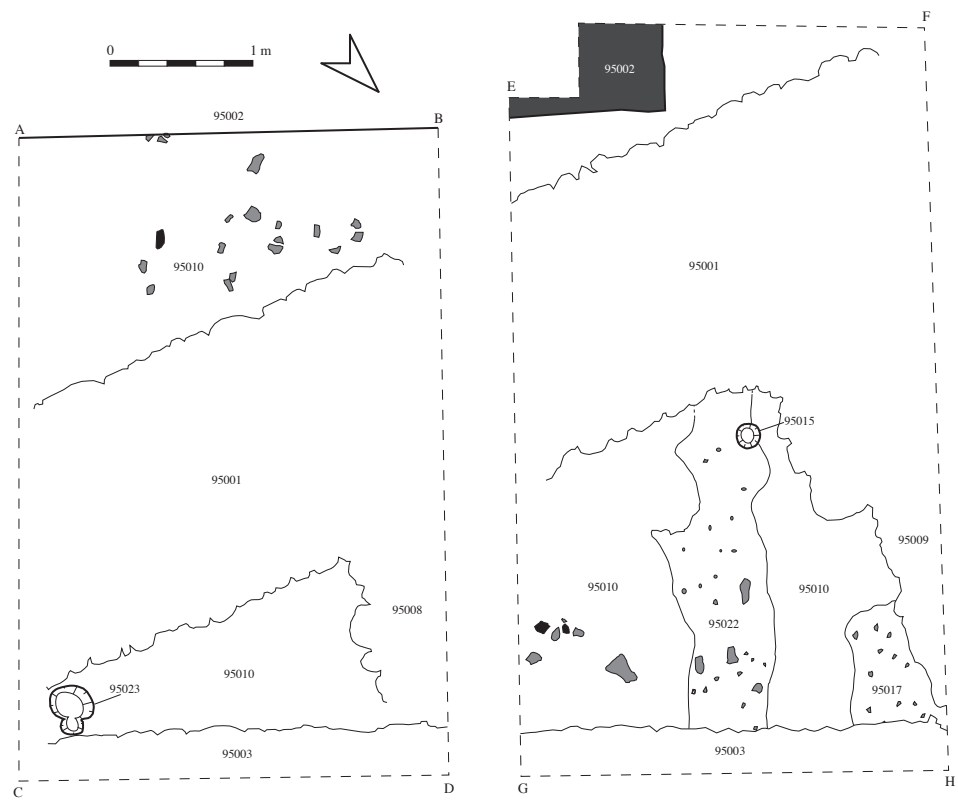

Fig. 4:1. Libkovice - St. Nichols church. Intervention 95: first horizon, 1st-2nd settlement phase. 95023 - post hole; 95017 and 95022 - areas covered with gravel, pebbles and little stones. Plan by V. Mráz and P. Vařeka.

Obr. 4:1. Libkovice - kostel sv. Mikuláše. Sonda 95: horizont první, 1.-2. sídelní fáze. 95023 - sloupová jáma; 95017 a 95022 pásy štětované štěrkem, kamínky a oblázky. Plán V. Mráz a P. Vařeka.
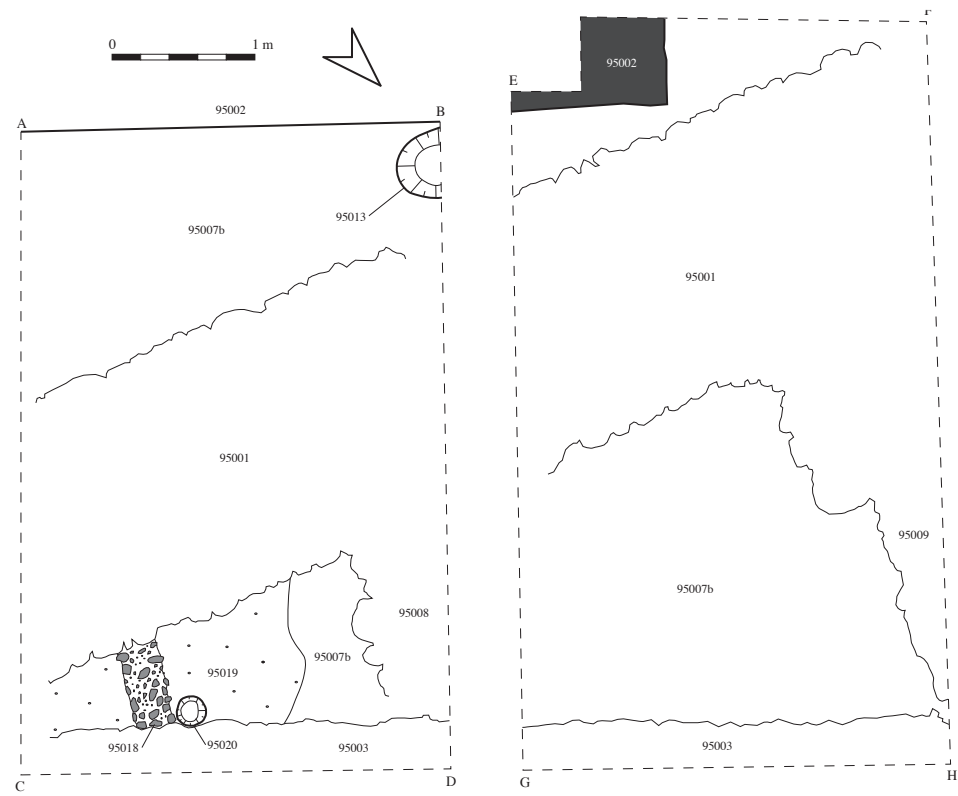

Fig. 4:2. Libkovice - St. Nichols church. Intervention 95: first horizon, 3rd settlement phase with construction remains. 95013 and 95020 - post holes; 95018 - stone footing of a timber wall; 95019 - burnt remains of a wooden construction. Plan by V. Mráz and P. Vařeka.

Obr. 4:2. Libkovice - kostel sv. Mikuláše. Sonda 95: horizont první, 3. sídelní fáze s relikty konstrukcí. 95013 a 95020 - sloupové jámy; 95018 - kamenný podklad dřevěné konstrukce; 95019 - spáleništní vrstva dřevěné konstrukce. Plán V. Mráz a P. Vařeka. 

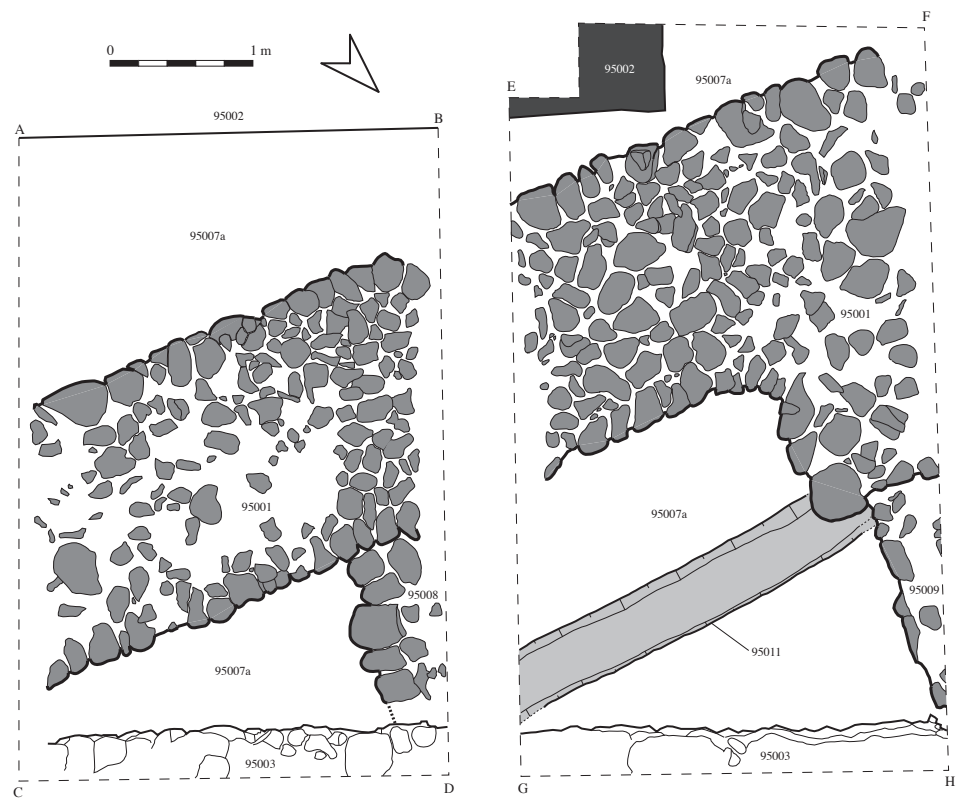

Fig. 4:3. Libkovice - St. Nichols church. Intervention 95: second and third horizon. 95001, 95008 and 95009 - foundations of the Gothic church; 95011 - probable foundation trench of the earlier timber church; 95002 and wall 95003 - modern church and its enclosure. Plan by V. Mráz and P. Vařeka.

Obr. 4:3. Libkovice - kostel sv. Mikuláše. Sonda 95: horizont druhý a třetí. 95001, 95008,95009 - základy gotického kostela; 95011 - pravděpodobný základový výkop staršího dřevěného kostela; 95002 a 95003 - novodobý kostel a jeho ohrazení. Plán V. Mráz a P. Vařeka.

The second horizon brought an end of the previous settlement. Gradual increase of settlement stratigraphy was terminated and a large east-west oriented groove (95011) was made in the terrain, which is represented by the surface of the layer 95007a. This linear feature was situated parallel with the presbytery wall in the distance of $0.9-1 \mathrm{~m}$. It reached $0.6 \mathrm{~m}$ in width and $0.3 \mathrm{~m}$ in depth and it was filled with coarse sand and pebbles without any archaeological finds (Fig. 4:3, Fig. 5 and Fig.6:2). The groove was cut by the stone walls of the Gothic church, the building of which represents the third horizon (see above). Subsequent contexts can be linked to the older church demolition (horizon four; 95005, 95006, 95026) and building of the new one at the end of the 19th century (horizon five; 95002) as well as subsequent construction of the wall around the modern church and related terrain flattening (horizon four; 95004, 95003).

The linear feature represents very likely remain of a substantial timber building which don't have any analogies in the rural housing of this period. According to the character of the groove and its stratigraphical and spatial context, it cannot be excluded that it may indicate the earliest sacral building represented by a wooden church. The groove might be interpreted as a negative of a wooden construction that was set into the ground. Concerning its width, however, it is more likely that this feature represents a negative of the stone foundation of a wooden wall which was dismantled and reutilized during construction of the new church. Dating of this feature can be made only indirectly. Its construction is connected with the termination of the latest phase of the first settlement horizon. Due to the developing chronology of early and high medieval pottery in North-West Bohemia, only broader dating to the 12 th-12th/13th century can be provided. The upper limit of the existence of this building is delimited by the establishment of the stone gothic church prior to 1300 (third horizon). 


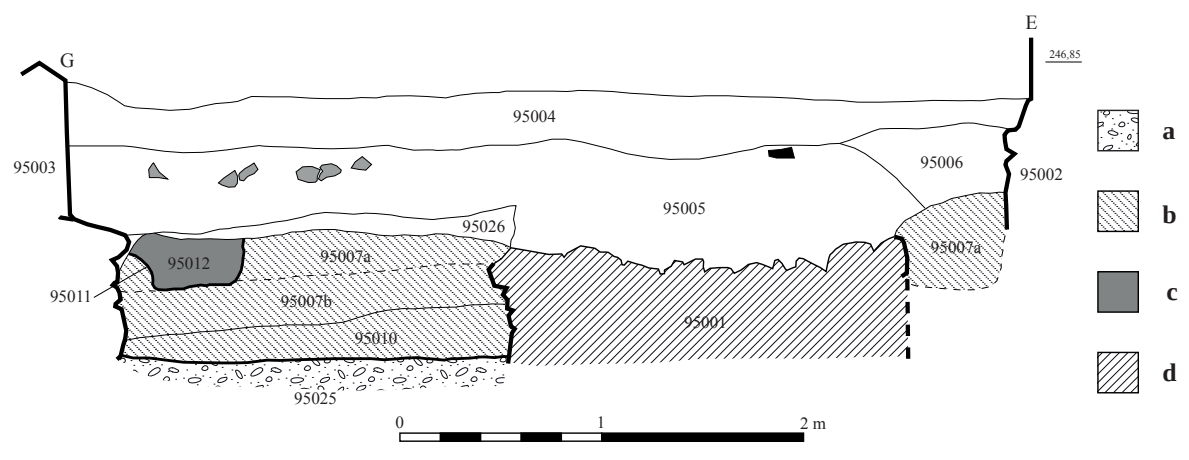

Fig. 5. Libkovice - St. Nichols church. Intervention 95: profile G-E. a - geological subsoil; b - earlier settlement layers; $c$ - probable foundation trench of the earliest timber church; $d$ - foundation wall of the Gothic church. Drawing by V. Mráz and P. Vařeka.

Obr. 5. Libkovice - kostel sv. Mikuláše. Sonda 95: profil G-E. a - geologické podloží; b-souvrství staršího sídliště; c-možný základový výkop staršího dřevěného kostela; d - základy gotického kostela. Kresba V. Mráz a P. Vařeka.

\section{Interpretation and discussion}

The rescue excavations of the now-demolished St. Nicholas church from the 1890s revealed foundations of its early Gothic 13th century predecessor. Earlier linear feature indicates the remains of substantial timber building of some kind, which might be hypothetically linked to an "ecclesia lignea", as wooden churches were referred to in medieval documentary evidence (cf. Sommer 1987). Contrary to Western and Northern Europe, in Bohemia there is limited archaeological evidence of medieval wooden churches; there are less than ten examples, but existence of others can be supposed. Direct and indirect evidence interpreted as the relics of timber churches includes burnt wooden walls, ${ }^{5}$ negatives of wooden walls in the form of a narrow groove, ${ }^{6}$ and the stone foundations of a no longer existing wooden construction. ${ }^{7}$ Explanation of the Libkovice find of a substantial groove as the remains of a dismantled stone foundation (foundation trench) offers another type of possible indirect evidence.

The closest analogy can be found in the nearby village of Nesvětice (cadastral territory of Libkovice), which was deserted in the 15th century. Excavations of the remains of the local parish church of St. Catherine and adjacent churchyard led by V. Brych unearthed the stone foundation of a presumed wooden sacral building of the same layout and similar size as the Libkovice early Gothic stone church (a nearly square nave of $5.5 \times 5 \mathrm{~m}$ with a rectangular presbytery of a total length of $13 \mathrm{~m}$. The foundation, which was built of small stones bound by clay, was based in a trench of nearly the same size as in Libkovice, reaching $0.8 \mathrm{~m}$ in width and $0.2-0.25 \mathrm{~m}$ in depth. The sacral building is generally dated to the 13th century and its destruction, indicated by several finds of burnt daub, can be linked to the phase of the village's desertion in the 15th century (Brych 1989). Though the layout of the earliest Libkovice church is yet unknown, it might have timber

\footnotetext{
5 Burnt timbers indicate a wooden church built probably in the 13th century in Zákupy (Distr. of Česká Lípa) which was replaced by a stone church of an unknown patrocinium after 1300 (Gabriel 2008). Similar situation can be found in Dobrá Voda, St. Vintír/Günther Church (Distr. of Klatovy), where burnt remains of likely a timber church from the 13th-15th century were excavated (Čechura 2005, 363). Post-holes indicating very small structures on two early medieval cemeteries may be interpreted as cultic buildings of some kind (Třeštík-Sommer 2009, 261-262).

6 Planá (Distr. of Tachov) - St. Peter and Paul church; a groove indicating an earlier sacral building was found in the interior of the stone-built Romanesque church; dating probably to the 12th century (Hanzlíková-Frýda 1982, 425-426).

7 Čečovice (Distr. of Domažlice) - clay bound stone foundation indicating a timber sacral building dated to the 14th century was unearthed in the interior of the later church Čechura 2005, 362). Nesvětice (Distr. of Most), St. Catherine church (Brych 1989; see below).
} 


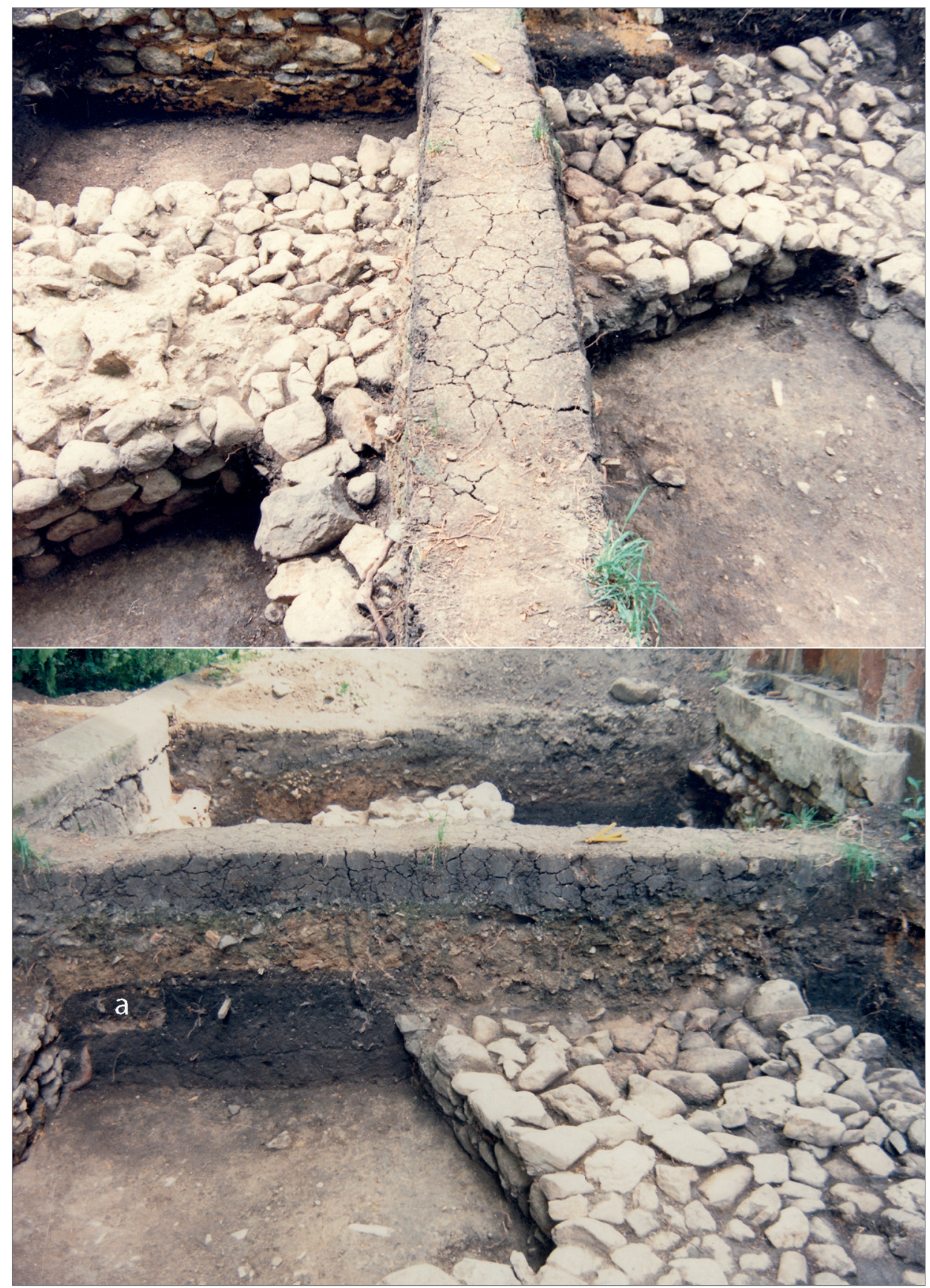

Fig. 6:1. Libkovice - St. Nicolas church. Intervention 95: foundation of the Gothic church - view from the North. Photo by P. Vařeka.

Obr. 6:1. Libkovice - kostel sv. Mikuláše. Sonda 95: základy gotického kostela - pohled od severu. Foto P. Vařeka.

Fig. 6:2: Libkovice - St. Nicolas church. Intervention 95: foundation of the Gothic church and profile G-E. a - probable foundation trench of the earliest timber church. Photo by P. Vařeka.

Obr. 6:2. Libkovice - kostel sv. Mikuláše. Sonda 95: základy gotického kostela a profil G-E. a - možný základový výkop staršího dřevěného kostela. Foto $P$. Vařeka. 


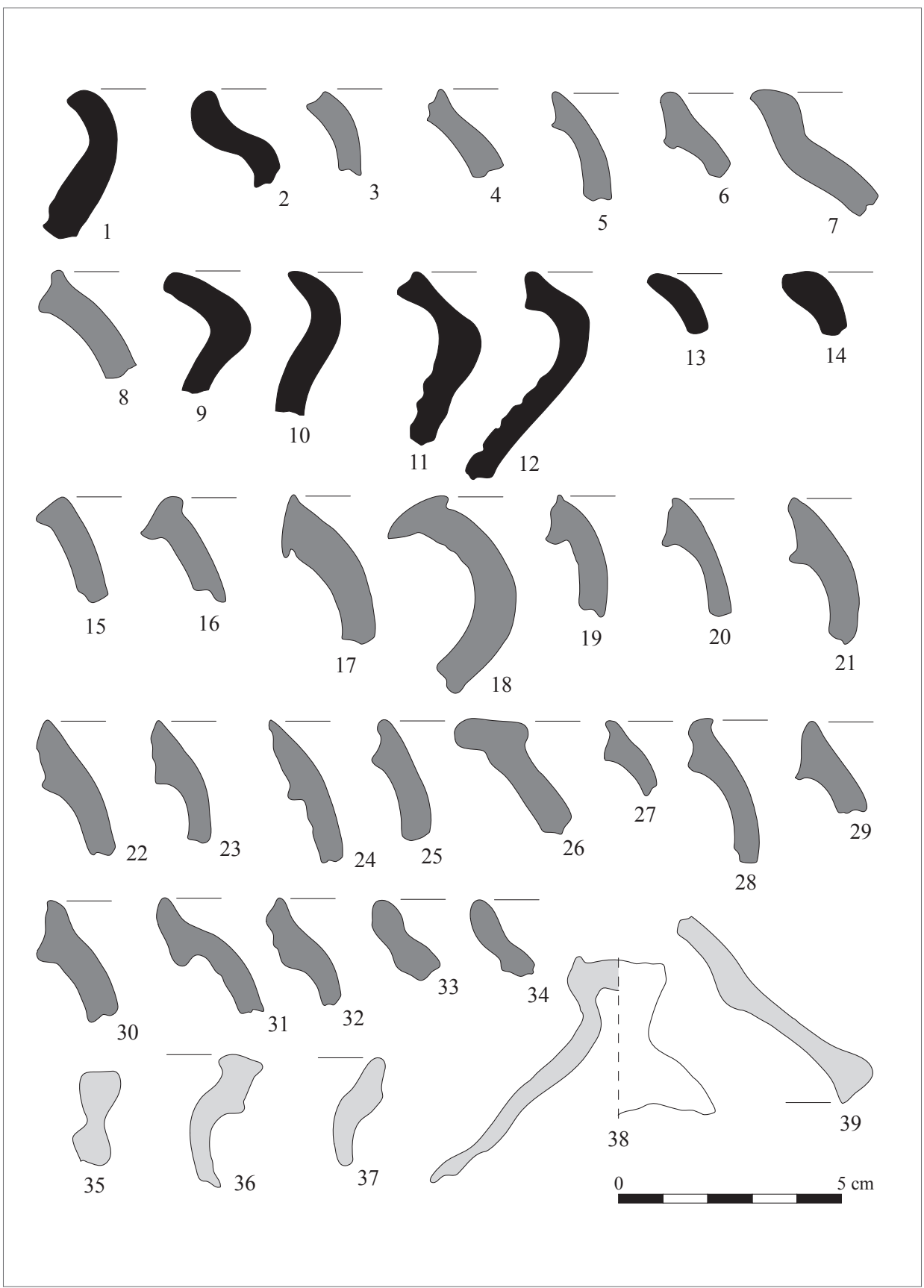

Fig. 7. Libkovice - St. Nichols church. 1-34 - rim fragments of ceramic vessels from earlier settlement; 1-7 - layer 95010; 8 - layer 95019; 9-34 - layer 95007a and 95007b; 35-39 - pottery fragments from the foundation of the vestry (wall 95009). Black - pottery fabrics belonging to the earlier ceramic tradition (presumably an intrusion); dark grey - pottery fabric of the later early medieval ceramic fabrics; light grey - late medieval ceramic. Drawing by P. Vařeka.

Obr. 7. Libkovice - kostel dv. Mikuláše. 1-34 - okrajové profilace nádob ze staršího sídliště; 1-7 - vrstva 95010; 8 - vrstva 95019; 9-34 - vrstva 95007a-95007b; 35-39 - fragment keramiky ze zdiva sakristie (zdivo 95009). Černě - středohradištní hrnčířské zboží (pravděpodobně intruze); tmavě šedě - mladohradištní - pozdněhradištní keramické zboží; světle šedá - pozdně středověká keramika. Kresba P. Vařeka. 
walls set on solid stone foundations similarly to the neighbouring parish church in Nesvětice which, however, was never replaced by a stone-built successor.

Recent rescue research east and south of the Nesvertice church revealed large cemetery consisting of nearly 800 graves which can be dated to the 11th-13th century. Due to only preliminary character of publications the relationship of the church and earlier burial activity is tenuous (Čech 2015; 2018; Čech-Křivánek-Soukup 2014). However, the Nesvětice cemetery, which is situated only $1.2 \mathrm{~km}$ far from the historical core of Libkovice, must have represented an important component of the dense early medieval settlement pattern of the micro-region.

The establishment of a dense network of village parish churches with adjacent cemeteries represented an essential change of the medieval settlement structure and burial practices in medieval rural Europe (Klápště 2010). In Bohemia, a large parish organization was instituted in the 10th century with churches situated in hillforts, which were centres of early medieval state power and played a crucial role in the Christianisation of the country (Sláma 1988, 74-75; Třeštík-Sommer 2009, 251-252, 258, 268). Rural communities, however, buried their dead in row cemeteries placed in the landscape outside settlements (Klápště 1994, 137-140; 2010, 217-220). ${ }^{8}$ The usual distance of several hundred metres between habitation and burial areas is understood as both a physical and symbolic separation of the world of the living and the realm of the dead. The persistence of pre-Christian beliefs is indicated by grave-goods documented by archaeological excavations. Dating of coins found in graves showed that these cemeteries were generally abandoned around 1100 but some may have been in existence until the early 13th century (Klápště 2010, 217-220). It is assumed that row cemeteries in the open landscape were replaced by graveyards attached to newly built village parish churches; nevertheless, the archaeological evidence of this process is still very limited and there is also a lack of preserved village churches dated to the early 12th century (see Klápště 2010, 218; Štefan-Varadzin 2018, 23-24). It has been also presumed that the earliest parish churches in rural settlements may have been built of wood (Klápště 2010, 223).

In Libkovice, some isolated finds indicate an early medieval cemetery in the area south of the village (Klápště 1994, 134). The shift of the burial area to the village must have represented a significant transformation of the social system embodied by an alteration of burial practices, settlement topography and symbolic perception of the landscape. The church with adjacent graveyard created the new spiritual as well as physical core of the village community; the space for the ancestors was no longer separated, and the living and dead shared the same settlement area. Thus Libkovice research provides a unique material record of the process of the village parishes' introduction, the dense network of which made it possible to perform thorough church administration and oversight of peasants.

The archaeological context demonstrates that the village church was built on top of a thick stratigraphy of settlement remains, including what are likely to be traces of houses. Frequent pottery finds from the fills of graves also show that burial activity must have disturbed some earlier settlement debris. It is evident that the parish church with adjacent graveyard was established within an existing settlement which can be dated to the 10th/11th-12th/13th century. The ceramic assemblage from the latest layer of the settlement stratigraphy provides an ante quem date of the supposed timber church foundation to the 12th-12th/13th century. Dating of the early Gothic church to the second and third quarter of the 13th century is only general based on its architectural form. Pottery finds from the masonry of the vestry indicate its construction in the 14th-15th century. Absence of any mention of the church in the charter from 1240 (see above) can be explained by the fact that it was not part of the property transaction. Foundation of the supposed timber church can be hypothetically linked to the main land owner of the region, the Hrabišici Lords, who also generously donated the Osek Cistercian Monastery (Velímský 2002, 32-33, 88-89). It

8 Official interdicts of such burials "in agris sive in silvis" or "sepulturas, que fiebant in silvis et in campis" were mentioned in Cosmas chronicle from the early 12 th century (KOSMAS, 88,161 ). 
is very likely that the monastery acquired the patronage over the church during the 13th century and retained it until the Communist era. It is also highly possible that the Cistercians established the new sacral building and that the first mentioned priest (REGESTA IV, No. 1851, 737) already administered a stone church in 1282.

Settlement remains from the 10th/11th-12th/13th century were also documented in other parts of the village around the church. Plotting these contexts on the map shows an outline of a settlement area which may represent a nucleation core of the village on the right bank of the stream. Due to limited excavations on the 1990s, it cannot be proved that the settlement also included the area north of the stream; however, some archaeological situations indicate settlement activities from this period here. The irregularly oval area of the graveyard around the church was marked by a wall depicted on the 1842 cadastral map, which is also clearly visible on the old drawing (see above). Foundation of this thick stone-built wall was found in the late 1990s during further excavations. It cannot be ruled out that the Gothic church surrounded by a massive wall also may have been used as a refugium for the village community. The churchyard is lined by the stream on the northern side and its branch, which is also visible on the old map, can be interpreted as a mill race originally aiming north-west towards the lower mill. Excavations showed that this section of the mill race, which marked the church and graveyard from the north-west, was filled in during the modern era and replaced by a tunnel under the ground. The orientation of the early Gothic church apparently does not correspond to the regular layout of the village, which was formed in the late 13th-13th/14th century according to archaeological research results. This fact supports the dating of the church and its link to the earlier settlement. As late as in the end of the 19 th century, the modern church was built with regard to the urbanistic form of the village created six centuries ago.

\section{Conclusions}

Exploratory and rescue excavations of the Libkovice village which were carried out during its demolition in the 1990s caused by the planned coal mining produced a large archaeology data set in terms of the settlement's development since prehistory and through the Middle Ages, postmedieval and modern period, until the sad ending of the human settlement in this part of Northwest Bohemia. One of the most significant phases is represented by the nucleation core of the village from the 10th/11th - early 13th century, which substituted an earlier dispersed settlement pattern. Target excavations of the modern St. Nicholas Church from the end of the 19th century revealed its early Gothic predecessor dated to the period prior to 1300 with adjacent graveyard. Remains of an older building of the same orientation were also found and may hypothetically indicate an earlier sacral building (12th-12th/13th century?). Establishment of the parish church and churchyard represented an important component of the process of the village's formation. Research results have contributed to the knowledge of the process of the establishment of medieval village parish organization. On-going large-scale rescue excavations of the former Libkovice village, which builds upon the archaeological research of the 1990s, give us the opportunity to verify results of the field research in the 1990s and broaden our current knowledge of this site, which has constituted an important reference sample for the programme focused on inhabited historical villages in Bohemia and also in wider European context. Detection and excavation of the early medieval row cemetery outside the village is another important task for future rescue activities prior to the advance of the coal mine. Archaeological research of both the cemetery connected with the archaic early medieval tradition and the churchyard representing an important component of the high medieval transformation may provide comparative evidence of great importance.

This article was supported by the project "Community Archaeology in Rural Environments - Meeting Societal Challenges" (Cultural Heritage - A Challenge for Europe, JPICH Heritage in Changing Environments). 


\section{Documentary sources}

Berní rula: National Archive, inv. No. 16, fol. 89.

CDB III/2: Codex diplomaticus et epistolaris regni Bohemiae (1238-1240) (Friedrich, I. G.- Z. Kristen, Z., edd.). Praha 1962.

Exaequatorium dominicale: Exaequatorium dominicale - Tereziánský katastr, Fasse 1713. National Archive, inv. No. 1861, fol. 51.

KOSMAS: Cosmae Pragensis Chronica Boemorum. Die Chronik der Böhmen des Cosmas von Prag, Monumenta Germaniae historica, Scriptores rerum Germanicarum, Nova series II. (Bretholz, B., ed.). Berlin 1923.

LC VI: Libri confirmationum ad beneficia ecclesiastica pragensem per archidioecesim. Liber sextus ab anno 1399 usque ad annum 1410 (Emler, J., ed.). Pragae 1883.

REGESTA IV: Regesta diplomatica nec non epistolaria Bohemiae et Moraviae IV (Emler, J., ed.). Pragae 1892.

URBAR: Urbar Register des Stiftes Osek was ein ider unterthaner zugeben oder zu zinsen such sonst von Robott und Schwarwergk zuthuen verpflicht wie sie sich dan selbst darzu bekendt haben. SOA Litoměřice, Sign. UR-SM - inv. No. 69, kart. 5.

\section{Bibliography}

BENEŠ, J., 1991a: Benutzung der Korrelationskarten beim Studium der Siedlungskontinuität und -diskontinuität am Beispiel in der Mikroregion Lomský Potok in Nordwest-Böhmen, Veröffentlichungen des Museums für Ur- und Frühgeschichte Potsdam 25, 55-64.

- 1991b: The Lomský potok project: investigation of prehistoric settlement of a microregion with large-scale soil transfers. In: Archaeology in Bohemia 1986-1990, 178-184. Prague.

- 1995a: Deset let archeologického výzkumu zemědělského pravěku v povodí Lomského a Loučenského potoka v severozápadních Čechách (1983-1992). In: Archeologické výzkumy v severozápadních Čechách (Blažek, J.-Meduna, P., edd.), 63-80. Most.

- 1995b: Erosion and accumulation processes in the late holocene of Bohemia, in relation to prehistoric and mediaeval Iandscape occupation. In: Whither Archaeology? A volume dedicated to E. Neustupny (Kuna, M.-Venclova, V., edd.), 133-144. Praha.

BENEŠ, J.-KOUTECKÝ, D., 1987: Die Erforschung der Mikroregion Lomský potok - Probleme und Perspektive. In: Archäologische Rettungsktätigkeit in den Braunkohlengebieten (Symposium Most 1986) (Černá, E., ed.), 31-38. Prag.

BENEŠ, J.-KUNA, M.-PEŠKE, L.-ZVELEBIL, M., 1992: Rekonstrukce staré kulturní krajiny v severní části Čech. Československo-britský projekt po první sezóně výzkumu, AR XLIV, 33-42.

BENEŠ, J.-ZVELEBIL, M., 1996: A historical interactive landscape in the heart of Europe: the case of Bohemia. In: The Archaeology and Anthropology of Landscape. Shaping your landscape (Ucko, J.-Layton, R., edd.), 73-93. London - New York.

BRYCH, V., 1989: Nesvětice, zaniklá středověká ves na Mostecku - Nesvětice, mittelalterliche Ortswüstung im Bez. Most, AH 14, 311-318.

BUBENÍK, J., 1975: Slovanské sídliště u Břežánek, okr. Teplice, AR XXVII, 642-650.

BUBENÍK, J.-VELÍMSKÝ, T., 1986: Archeologický výzkum polokulturní lokality u Jenišova Újezda, okr. Teplice, Archeologické studijní materiály 15, 42-49.

BUDINSKÝ, P., 1968: Libkovice (Mariánské Radčice), Jenišův Újezd, Hostomice. Významná naleziště doby laténské v Podkrušnohoří. I. část. Libkovice (Mariánské Radčice). Teplice.

- 1970: Libkovice (Mariánské Radčice), Jenišův Újezd, Hostomice. Významná naleziště doby laténské v Podkrušnohoří. II. část. Jenišův Újezd. Teplice.

ČECH, P., 2015: Druhá sezóna odkryvu v Nesvěticích (k. ú. Libkovice). In: Archeologické výzkumy v Čechách 2014. Sborník referátů z informačního kolokvia. Zprávy České archeologické společnosti Supplément 97, 39. Praha. 
- 2018: Pátý rok výzkumu raně stř̌edověkého pohřebiště Nesvětice (okr. Most) z 11.-13. stol. In: Archeologické výzkumy v Čechách 2017. Sborník referátů z informačního kolokvia, Zprávy České archeologické společnosti - Supplément 109, 30. Praha.

ČECH, P.-KŘIVÁNEK, R.-SOUKUP, M., 2014: Interdisciplinární výzkum raně středověkého pohřebišš v Nesvěticích (k. ú. Libkovice u Mostu, okr. Most). In: Archeologické výzkumy v Čechách 2013. Sborník referátů z informačního kolokvia, Zprávy České archeologické společnosti - Supplément 96, 29-31. Praha.

ČECHURA, M., 2005: Archeologický výzkum kostelů v západních Čechách - Archäologische Erforschung der Kirchen in Westböhmen, AH 30, 359-376.

DITTRICH, T.-ŠKABRADA, J., 1984: Libkovice (okres Most) průzkum a hodnocení objektů lidové architektury. Rkp., Státní ústav pro rekonstrukci památkových měst a objektů v Praze.

DOHNAL, M.-KORENÝ, R.-KOUCKÝ, K.-PROCHÁZKA, L.-ŠAMATA, J., 2001: Obděnice čp. 4 (okr. Př́ibram). Dějiny usedlosti ve světle etnografických, archeologických, písemných a paleozoologických pramenů - No 4, Obděnice (Př́ibram district). The history of a homestead in the light of ethnographic, archaeological, written and palaeozoological sources, ASČ 5, 721-738.

DOHNAL, M.-VAŘEKA, P., 1997: Výzkum novověké vesnické usedlosti v Srlíně (okr. Písek) - svědectví archeologických a písemných pramenů, AVJČ 10, 1997, 84-106.

GABRIEL, F., 2008: Vývoj sídelní aglomerace Zákup u České Lípy, ČSPS 116, $20-28$.

GOCKELER, S.-REEVE, H., 1997: Libkovice: Zdař Bůh. Praha.

HANZLÍKOVÁ, H.-FRÝDA, F., 1982: Románský kostel Petra a Pavla v Plané, okr. Tachov - Romanische Peter-Paul Kirche in Planá, Bez. Tachov, AH 7, 423-428.

HINZ, H., ed., 1977: Bosau. Untersuchungen einer Siedlungskammer in Ostholstein II. Neumünster.

KLÁPŠTĚ, J., 1975: Archeologický výzkum města Mostu v letech 1971 až 1973. Dosavadní výsledky a perspektivy výzkumu, AR XXVII, 262-270.

- 2002: Úvod. Povaha terénních situací a př́ílušných nálezových souborů. In: Archeologie středověkého domu v Mostě (čp. 226) (Klápště, J., ed.), 7-9. Praha.

- 1994a: Pamět' krajiny středověkého Mostecka. Most.

- 1994b: Změna - středověká transformace a její předpoklady. In: Mediaevalia Archaeologica Bohemica 1993. PA - Supplementum 2 (Fridrich, J.-Klápště, J.-Vařeka, P., edd.), 9-59. Praha.

- 2010: Bohemia plena est ecclesiis et religione divina. In: Čechy jsou plné kostelů - Bohemia plena est eclesiis. Kniha k poctě PhDr. Anežky Merhautové, DrSc. (Studničková, M., ed.), 217-277. Praha.

KLÁPŠTĚ, J.-SLAVÍČEK, A.-VELÍMSKÝ, T., 1976: Archeologický výzkum města Mostu 1970/1975. Most.

KLÁPŠTĚ, J.-VELÍMSKÝ, T., 1975: Příspěvek ke studiu počátků města Mostu, AR XXVII, 651-672.

KOL., 1978: Retrospektivní lexikon obcí Československé socialistické republiky 1850-1970. Svazek 1. Praha.

LEWIS, C., 2014: The Power of Pits: Archaeology, outreach and research in living landscapes. In: Living in the Landscape (Boyle, K.-Rabett, R.-Hunt, C., edd.), 321-338. Cambridge. https://doi.org/10.3390/h4030393

LEWIS, C., 2015: Archaeological Excavation and Deep Mapping in Historic Rural Communities, Humanities 2015/4, 393-417.

LEWIS, C., 2016: Disaster Recovery? - New archaeological evidence from eastern England for the impact of the 'calamitous' 14th century, Antiquity 90/351, 777-797. https://doi.org/10.15184/aqy.2016.69

LÍBAL, D., 1984: Gotická architektura. In: Dějiny českého výtvarného umění I/1. Od počátků do konce středověku (Chadraba, R., ed.), 144-215. Praha.

LUXA, J., 1997: Z historie hornictví k současnosti dolování na Bílinsku. Teplice.

MATĚJČEK, J., 1984: Vývoj uhelného průmyslu v českých zemích po průmyslovou revoluci (do roku 1914). Praha.

MEDUNA, P., ed., 2012: Raně středověké sídliště v Hrdlovce. Archeologické studijní materiály 20. Praha.

MEDUNA, P.-KYPTA, J.-ŠULC, J.-MATĚJEK, M., 2001: Vidim a Daminěves. Poznámky k vývoji stř̌edověké a novověké vesnice, ASČ 5, 689-720.

MILITKÝ, J.-VAŘEKA, P., 1997: Češnovice: Archeologický výzkum středověké a novověké vesnice na Českobudějovicku I. Pozdně středověký dům v usedlosti čp. 13, AVJČ 10, 58-79. 
NESLÁDEK, M.-NOVOTNÁ, H., 1985: Severočeský hnědouhelný revír, koncern Most. In: Uhelné hornictví v ČSSR (Majer, J. et al., edd.), 574-587. Ostrava.

NOVÁČEK, K., 1997: Př́́klad interpretace historického vývoje mikroreliéfu: Bdeněves u Plzně, AR XLIV, 495-503.

NOVÁČEK, K.-VAŘEKA, P., 1996: Archaeological research of present - day villages of a medieval origin in Bohemia, Ruralia I. PA - Supplementum 5, 314-316.

- 1997: Archeologický výzkum žijících vesnic středověkého původu v Čechách - Archaological research of present-day villages of a medieval origin in Bohemia, ASČ 1, 429-444.

NOVOSADOVÁ, O., 1988: Libkovice, kostel sv. Mikuláše, poutní kaple. Stavebně historický průzkum. Rkp., Státní ústav pro rekonstrukci památkových měst a objektů v Praze.

OEXLE, J., ed., 2002: Kirche und Friedhof von Breunsdorf. Beiträge zur Sakralarchitektur und zum Totenbrauchtum in einem Dorf südlich von Leipzig. Breunsdorf 2. Veröffentlichungen des Landesamtes für Archäologie mit Landesmuseum für Vorgeschichte 35. Dresden.

PEŠEK, J. et al., 2010: Terciérní pánve a ložiska hnědého uhlí České republiky. Praha.

PEŠEK, J.-SIVEK, M., 2012: Uhlonosné pánve a ložiska černého a hnědého uhlí České republiky. Praha.

SCHALLER, J., 1781: Topographie des Königkreichs Böhmens V. Leutmeritzer Kreis. Prag.

SLÁMA, J., 1988: Střední Čechy v raném středověku. Archeologie o počátcích přemyslovského státu. Praehistorica XIV. Praha.

SMOLNIK, R., ed., 2011: Breunsdorf - Ein verschwundenes Dorf im westsächsischen Braunkohlenrevier. Archäologischer Befund und schriftliche Überlieferung. Breunsdorf 3. Veröffentlichungen des Landesamtes für Archäologie mit Landesmuseum für Vorgeschichte 56. Dresden.

SOMMER, J. G., 1833: Das Königreich Böhmen I. Das Leitmeritzer Kreis. Prag.

SOMMER, P., 1987: Raně středověká „ecclesia lingnea“ a archeologie. In: Z pravěku do středověku. Sborník k 70. narozeninám doc. PhDr. Vladimíra Nekudy, DrSc. (Michna, P.-Nekuda, R.-Unger, J., edd.), 276-278. Brno.

ŠTEFAN, I.-VARADZIN, L., 2018: Sít', z níž nevyklouzne jediná ryba. Počátky farní organizace a archeologie, Dějiny a současnost $9,21-24$.

TŘEŠTíK, D.-SOMMER, P., 2009: Cesta ke křest’anské společnosti. In: Přemyslovci. Budování českého státu (Sommer, P.-Třeštík, D.-Žemlička, J., edd.), 241-271. Praha.

VAŘEKA, P., 1996: Zpráva o záchranném archeologickém výzkumu v Libkovicích (okr. Most) v roce 1996. Praha - Most. Rkp., Ústav archeologické památkové péče středních Čech.

- 2001: Proměny sídlištní struktury v mikroregionu Libkovic, okr. Most - Settlement structure transformation of the Libkovice microregion. A preliminary report. In: Archeologia przestrzeni. Metody i wyniki badań struktur osadniczych w dorzeczach górnej Łaby i Wisły (Kozłowski, J. K.-Neustupný, E., edd.), 85-94. Kraków.

- 2013: Př́íspěvek k podobě vesnického domu ze sklonku středověku na Českobudějovicku. Soubor mazanic s otisky konstrukcí z Češnovic, AVJČ 26, 207-236.

- 2018: The formation of the three-compartment rural house in medieval Central Europe as a cultural synthesis of different building traditions. In: Buildings of Medieval Europe. Studies in Landscape and Social Contexts of Medieval Buildings (Berryman, D.-Kerr, S., edd.), 139-155. Oxford Philadelphia.

VAŘEKA, P.-KOSTROUCH, F.-KOČÁR, P.-SƯVOVÁ, Z., 2010: Př́íspěvek ke studiu žijííćch vsí středověkého původu. Pozůstatky zástavby z pozdního středověku na parcele č.p. 121 v Mikulčicích - A contribution to research on deserted villages of Medieval origin. The remains of Late Medieval buildings on house plot no. 121 in Mikulčice, PV 51, 249-265.

VELÍMSKÝ, T., 2002: Hrabišici - páni z Rýzmburka. Praha.

WALDHAUSER, J. et al., 1978: Das keltische Gräberfeld bei Jenišův Újezd in Böhmen I., II. Teplice. 


\section{Shrnutí}

Archeologie kostela sv. Mikuláše ve zbořené obci Libkovice (Liquitz) - sondáže v letech 1995-1996 (Severočeská hnědouhelná pánev). Přríspěvek k výzkumu středověkých vesnických kostelů v Čechách

Zjištovací a předstihový záchranný výzkum v Libkovicích, který probíhal v 90. letech minulého století během demolice vesnice z důvodu plánované těžby uhlí, poskytl rozsáhlé soubory archeologických pramenů dovolující sledovat vývoj sídelního areálu od pravěku přes formování a proměny vesnice $\mathrm{v}$ průběhu středověku, novověku a $\mathrm{v}$ moderní době až do smutného konce osídlení této části severozápadních Čech. Jednu z nejdůležitějších vývojových fází představuje utváření nukleačního jádra vsi z 10./11. až první poloviny 13. století. Sondáž u farního kostela sv. Mikuláše z konce 19. století v letech 1995-1996 odhalila jeho raně gotického předchůdce ze 13. století a přilehlý hřbitov. Pozůstatky stavby stejné orientace tvořené žlabem, datované do 12.-12./13. století mohou indikovat starší sakrální stavbu. Založení farního kostela se hřbitovem bylo důležitou součástí procesu formování stabilizované vesnice. Výzkum přispěl ke studiu této zásadní proměny pohřebních areálů na prahu vrcholného středověku ve vesnickém prostředí spojené s vytvářením farní organizace, kdy starší pohřebiště umístěná mimo vesnická sídla byla opouštěna a nahrazována kostelními hřbitovy. Probíhající plošný odkryv Libkovic, představující v současnosti nejrozsáhlejší výzkum zaměřený na vesnické sídlo v České republice, který navazuje na výzkumy v 90. letech, nabízí jedinečnou příležitost získat ucelené poznatky o vývoji vesnice od raného středověku do jejího zániku před 30 lety. Zároveň tato lokalita představuje důležitý referenční vzorek pro studium existujících vsí stř̌edověkého původu na našem území i v širším evropském kontextu. Jedním z důležitých úkolů záchranného výzkumu je nejen lokalizace a odkryv raně středověkého pohřebiště, ale také vzorkování moderního hřbitova z 19. a 20. století. Výzkum všech etap pohřebních areálů na katastru Libkovic využívaných v posledním tisíciletí, s navazujícím komplexním antropologickým vyhodnocením s využitím moderních analytických metod, může poskytnout unikátní informace o jedné vesnické komunitě.

doc. PhDr. Pavel Vařeka, Ph.D., Katedra archeologie Fakulty filozofické Západočeské univerzity v Plzni, Sedláčkova 38, 30614 Plzeň, Česká republika, vareka@kar.zcu.cz 

